\title{
Reaping the Benefits from Global Value Chains
}




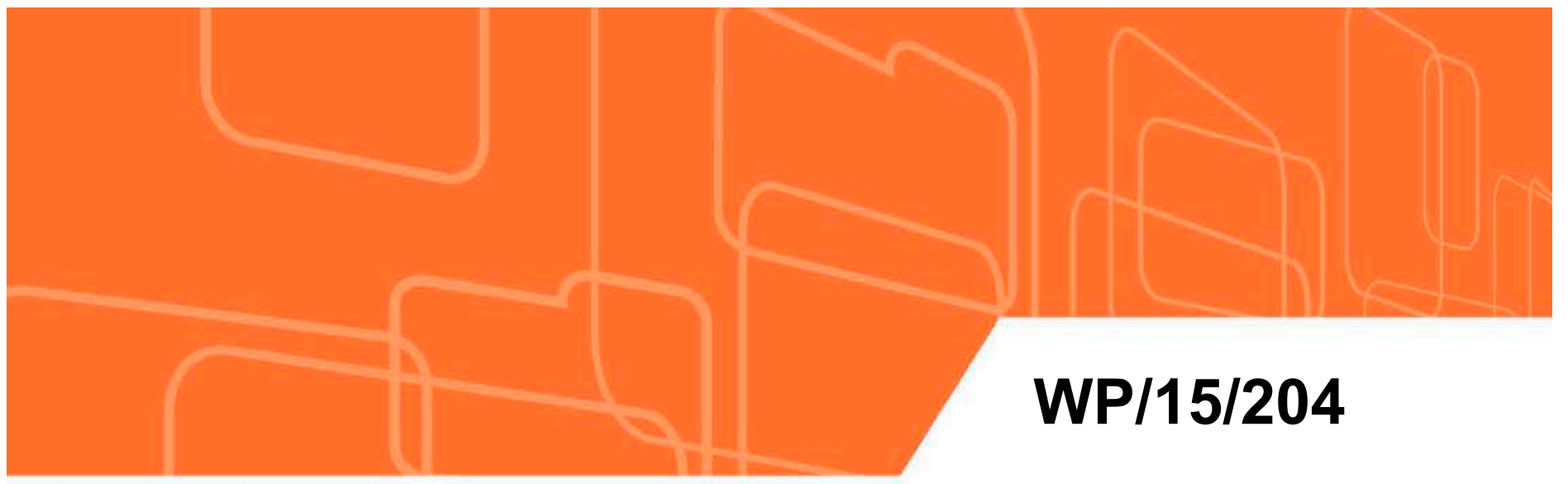

\section{IMF Working Paper}

\section{Reaping the Benefits from Global Value Chains}

by Kevin Cheng, Sidra Rehman, Dulani Seneviratne, and Shiny Zhang

IMF Working Papers describe research in progress by the author(s) and are published to elicit comments and to encourage debate. The views expressed in IMF Working Papers are those of the author(s) and do not necessarily represent the views of the IMF, its Executive Board, or IMF management.
I $N$
N T E R N A T I O N A L
$M O N E T A R Y$
$F \cup N D$ 


\title{
IMF Working Paper
}

Asia and Pacific Department

\section{Reaping the Benefits from Global Value Chains}

Prepared by Kevin Cheng, Sidra Rehman, Dulani Seneviratne, and Shiny Zhang

Authorized for distribution by Rachel van Elkan

September 2015

\section{IMF Working Papers describe research in progress by the author(s) and are published to elicit comments and to encourage debate. The views expressed in IMF Working Papers are those of the author(s) and do not necessarily represent the views of the IMF, its Executive Board, or IMF management.}

\begin{abstract}
Against the backdrop of the rise of global value chains (GVCs), particularly in Asia, this paper documents key developments of GVCs and investigates what factors cause economies to reap greater benefits from GVC participation. Key findings include: first, moving toward a more upstream position in production and raising economic complexity are associated with the country increasing its share of GVC value added. Second, fostering GVC participation and expanding the share of the domestic value added in a value chain require efforts to reduce trade barriers, enhance infrastructure, foster human capital formation, support research and development, and improve institutions.
\end{abstract}

JEL Classification Numbers: F10, F13, F60

Keywords: Global Value Chains; GVC, Economic Complexity; Growth;

Author's E-Mail Address: kcheng@imf.org; sr2700@columbia.edu;

dseneviratne@imf.org; shiny.zhang@mail.utoronto.ca 


\section{CONTENTS}

I. INTRODUCTION AND MAIN FINDINGS

II. A PRIMER ON ASIA'S GVC PARTICIPATION

III. HOW CAN ECONOMIES INCREASE THEIR GVC PARTICIPATION? .............. $\underline{8}$

A. Brief Overview of the Literature on Participation in Global Value Chains ............. $\underline{8}$

GVC Participation: Benefits .................................................................... $\frac{8}{9}$

GVC Participation: Drivers and Impediments ......................................... $\underline{9}$

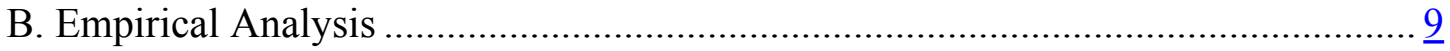

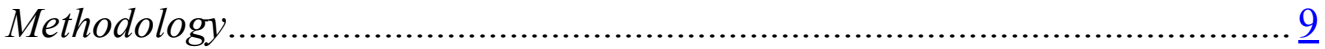

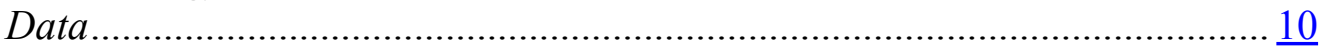

GVC Participation ......................................................................... $\frac{10}{10}$

Tariffs ........................................................................................... $\frac{10}{10}$

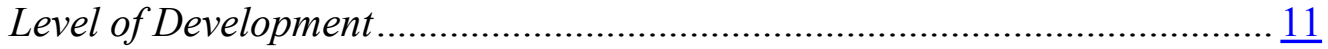

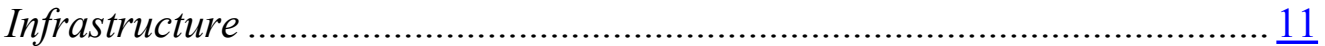

Human Capital Development ............................................................ $\frac{11}{11}$

Institutions and labor regulations ....................................................... 11

Other Trade Impediments .................................................................. 11

C. Results: Impact of Tariffs on Intermediate Goods ......................................... 12

D. Results: Impact of Fundamentals ............................................................... $\frac{13}{13}$

IV. HOW CAN AN ECONOMY CAPTURE A BIGGER SLICE OF THE GVC PIE? 14

A. Empirical Analysis: Methodology .............................................................. $\frac{14}{14}$

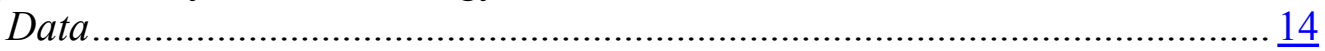

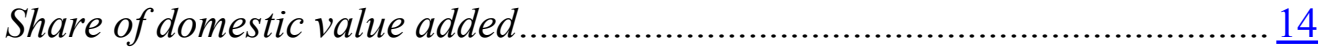

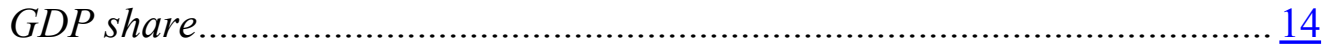

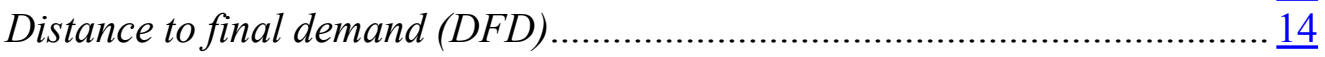

Economic complexity index (ECI) ............................................... $\frac{15}{15}$

Tariffs .................................................................................... 15

B. Results: Capturing a Bigger Slice of the GVC Pie ........................................... 15

V. CONCLUSIONS AND POLICY IMPLICATIONS ….................................... 17

APPENDIX: ECONOMIC COMPLEXITY IN ASIA ….................................. 19

A. Key Facts..........................................................................................

B. What Underlies Economic Complexity? ................................................ $\frac{20}{21}$

Econometric estimation and results .................................................... 21

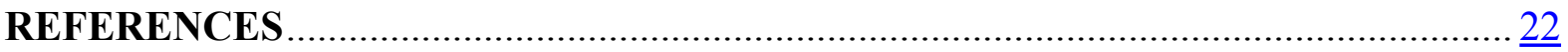




\section{Tables}

Table 1. Impact of Intermediate Goods Tariffs on ............................................................. 12

Table 2. Drivers of Improving Participation in Global Value-Chains .................................. $\frac{13}{16}$

Table 3. Capturing a Bigger Slice in Global Value Chains .................................................... 16

\section{Figures}

Figure 1. A Hypothesized "Smiley-Shaped" Relationship between Value-Added and GVC

Position

Figure 2. Participation in Global Value Chains: 1995 versus 2012 ......................................... $\frac{6}{7}$

Figure 3. Domestic Value-Added Share in Global Value-Added ............................................ 7

Figure 4. Upstreamness or Downstreamness …………................................................. $\frac{8}{2}$

Figure 5. Tariffs and GVC Participation........................................................................ 11

Figure 6. Illustrative Impact: GVC Participation ................................................................. 12

Figure 7. Assessing the link between Moving up GVCs, Upstreamness, Economic

Complexity, and Tariffs ................................................................................................... 16

Figure 8. Research and Development Expenditure and Upstreamness.................................. $\frac{16}{16}$

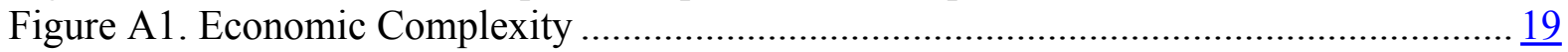

Figure A2. ECI by Region ....................................................................................

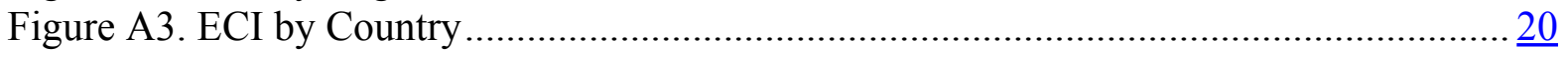

\section{Appendix Table}

Table A1. Drivers of Economic Complexity (Panel BMA Best Specification) …………….. 21 


\section{INTRODUCTION AND MAIN FINDINGS}

Over the past 30 years, production has become increasingly fragmented through the growing prevalence of global value chains (GVC), with components crossing numerous international borders. This has resulted in the faster growth of trade in intermediate inputs than the growth of trade in final goods. Asia has especially exemplified this new pattern of production: during 1995-2013, the region's trade in intermediate goods grew by a factor of six, while trade in final goods grew almost four times. This compares with fourfold and threefold increases, respectively, in the rest of the world.

The rise of GVCs calls for a different mindset in calibrating economic policies and, in particular, three major areas of policy considerations emerge:

- Integration into GVCs brings benefits beyond those traditionally associated with international trade in final goods, reflecting the more granular division of production and task specialization, which enables each participating country to exploit finer comparative advantage niches and raises the benefits from economies of scale and scope. Indeed, empirical evidence (such as Baldwin and Yan, 2014) shows that joining GVCs brings positive and significant gains in productivity. In this connection, a relevant policy question is: what factors and policies foster greater participation in GVCs?

- While participating in GVCs is largely beneficial, the GVC pie is not sliced up equally. As illustrated by the classic example of the iPod supply chain discussed by Dedrick, Kraemer, and Linden (2010), Apple - a U.S. based company - captures between one-third and one-half of an iPod's retail value, while Japanese firms such as Toshiba and Korean firms such as Samsung capture another major share as profits from producing high-value components such as the hard disk drive, display, and memory. By contrast, it is estimated that firms and workers in China capture no more than 2 percent from assembling the product. Given that capturing a bigger slice of the GVC pie is positively associated with productivity gains and higher per capita growth, a route for emerging Asian economies to escape the middle-income trap and for low-income economies to sustain strong growth over the medium term could be to reposition themselves toward higher-value stages of production. In this connection, an important policy question is what factors and policies cause economies to capture a bigger slice of the GVC pie?

This paper sheds light on these issues by focusing on the following: first, it documents key stylized facts about Asia's GVC participation, the positions within GVCs where Asian economies are situated, and how much of the GVC pie they capture. It then assesses which factors support GVC participation and help to raise the captured share of value added.

We rely on a unique OECD-WTO trade in value-added database on GVCs covering 57 countries, which became available only recently to address these questions-an impossible task just a few years ago. With a focus on Asia, our main findings include: 
- While the rise of GVCs has been ubiquitous across the globe, the expansion has been particularly pronounced among emerging Asian economies, including in the Association of Southeast Asian Nations (ASEAN). Moreover, Asian economies, particularly China, have captured an increasingly larger share of the value added generated in GVCs, even after adjusting for their recent rapid growth in relative economic size. Some advanced Asian economies, notably Korea, have also captured a bigger slice of the GVC pie in high-tech manufacturing. By contrast, adjusted for relative economic size, shares of value added in GVCs accruing to Japan and advanced economies outside Asia have declined.

- $\quad$ Asian economies, both advanced and emerging, have moved upstream (that is, providing intermediate inputs to other countries) rather than downstream (processing inputs from more upstream countries). Within high-tech manufacturing, advanced Asian economies remain significantly more specialized in upstream production than emerging Asian economies.

- $\quad$ Moving toward a more upstream position in production and raising economic complexity - a measure of an economy's productive knowledge and capabilities - are associated with a growing share of GVC value added captured by countries.

- A future challenge for policymakers, particularly in emerging and frontier economies, will be to foster GVC participation and to expand their share of the GVC pie while minimizing spillover risks associated with increased trade linkages. This will require reducing trade barriers, strengthening infrastructure, enhancing human capital formation, supporting research and development (R\&D), improving institutions, and strengthening resilience to shocks.

The remainder of the paper proceeds as follows: section II presents a primer on Asia's participation in GVCs; section III gauges how an economy can increase GVC participation; section IV examines how an economy can reap a larger slice of the GVC pie; and section V concludes.

\section{A Primer on Asia's GVC Participation}

\section{A. What are GVCs?}

A GVC is a network of interlinked stages of production for the manufacture of goods and services that straddles international borders. Typically, a GVC involves combining imported intermediate goods and domestic goods and services into products that are then exported for use as intermediates in the subsequent stage of production.

A standard GVC encompasses a number of production stages from upstream product conception to midstream assembly and then to downstream branding and marketing. As Figure 1 illustrates, a hypothesis in the GVC literature is that the relation between the production stage and value added exhibits a "smiley shape," suggesting that most value added in a GVC accrues to firms at the two ends of the production line, such as R\&D in the 
upstream and marketing in the downstream, with a smaller share of value added captured by assembling in the midstream.

\section{B. How Much Do Asian Economies Participate in GVCs?}

The extent to which an economy is engaged in a GVC can be measured by the GVC participation index, developed by Koopman and others (2010). Specifically, the index is defined as the ratio to a country's gross exports of the sum of foreign value added in domestic exports (backward participation) and domestically produced intermediates to be used in third countries (forward participation). This measure therefore excludes exports of final goods that have no foreign input content.

As Figure 2 shows, the extent of GVC participation has been relatively high in Asia, including in Korea, Malaysia, and the Philippines. The growth in GVC participation has been faster in Asia, particularly in ASEAN, than elsewhere in the world. China's participation also grew significantly during 1995-2012, likely reflecting its accession to the World Trade Organization in 2001, although China's participation rate is lower than the Asian average.

Figure 1

A Hypothesized "Smiley-Shaped" Relationship between Value-Added and GVC Position

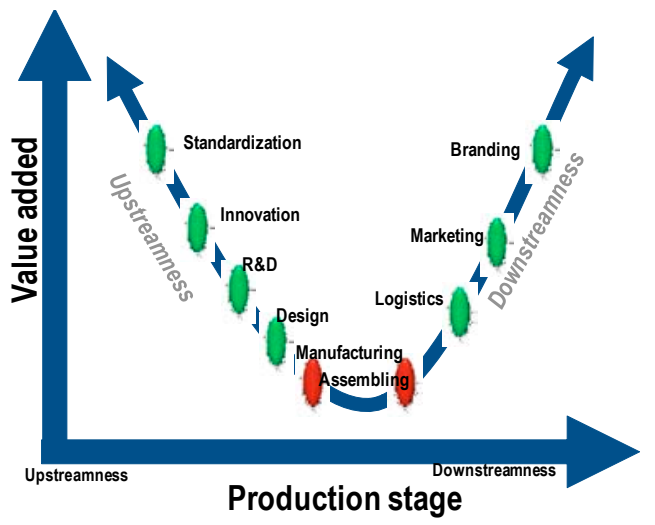

Source: World Economic Forum (2012). Note: $\mathrm{GVC}=$ global value chain
Figure 2

Participation in Global Value Chains: 1995 versus 2012

(Share of foreign inputs and domestically produced inputs used in third countries' exports in a country's gross exports; in percent)

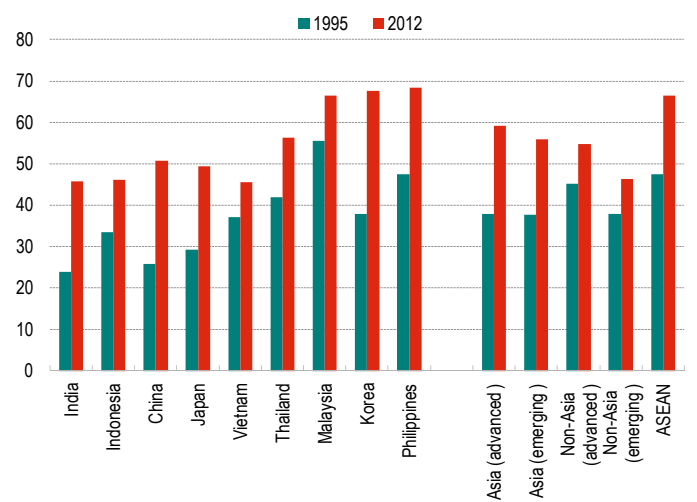

Sources: Organization for Economic Cooperation and Development and World Trade Organization, Trade in Value-Added database; and IMF staff estimates.

Note: Non-Asia includes comparable advanced and emerging economies.

\section{How Are GVCs Sliced Up?}

The GVC pie is not sliced up evenly and the shares of value added captured by economies vary over time and across sectors. Figure 3 illustrates the dynamics within GVCs for Asia and elsewhere. Key patterns can be summarized as follows: 
- $\quad$ During 1995-2009, both advanced and emerging economies in Asia gained (domestic) value-added shares in GVCs, but the gains were larger in low-tech than in high-tech manufacturing. Outside Asia, emerging economies gained, while advanced economies lost shares in GVCs during the same period (Figure 3, left panel).

- $\quad$ Among individual countries, Japan's value-added share in high-tech manufacturing was significantly eroded, while Korea gained during the same period. China has also moved up GVCs, but the gain is most significant in low-tech manufacturing.

Advanced economies outside Asia, notably Germany, the United Kingdom, and the United States, have lost value-added shares in high-tech manufacturing and gained in low-tech manufacturing (Figure 3, right panel).

Figure 3

\section{Domestic Value-Added Share in Global Value-Added}
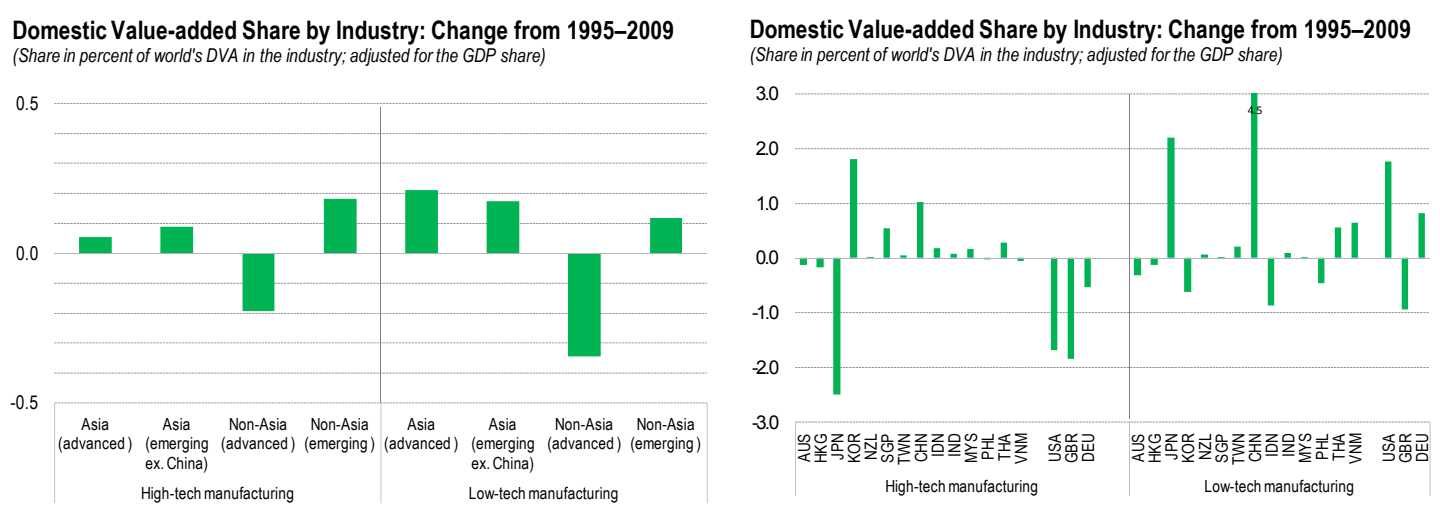

Sources: Organization for Economic Cooperation and Development and World Trade Organization, Trade in Value-Added database; and IMF staff estimates.

Note: DVA = domestic value-added.

High-tech manufacturing includes chemicals and nonmetallic mineral products, electrical and optical equipment, transportation equipment, machinery and equipment not elsewhere classified. Low-tech manufacturing includes food products, beverages and tobacco; textiles, textile products, leather and footwear; wood, paper, paper products; printing and publishing; basic metals and fabricated metal products; and manufacturing not elsewhere classified and recycling. DVA values are adjusted for the GDP share by taking the residual after regressing the DVA share on the GDP share. Countries are classified into advanced and emerging economies based on IMF, World Economic Outlook classifications. Country abbreviations use the three-letter International Organization for Standardization codes. Organization for Standardization country codes.

\section{Upstreamness versus Downstreamness}

Upstreamness (or downstreamness) refers to where an economy is located in a GVC. One measure, developed by Fally (2012), looks at how many stages of production remain before reaching final consumers. A long distance to final demand suggests that a country is upstream in the production process, such as a producer of raw materials or product design and research. Conversely, a short distance to final demand suggests that a country is downstream in the production process, such as customer service. 
Figure 4 illustrates the main characteristics of upstreamness and downstreamness in Asia. Key patterns include:

- In high-tech manufacturing, advanced economies tend to specialize in upstream stages, while emerging economies specialize in more downstream stages. This differentiation is more pronounced in Asia, where advanced Asia is more upstream than their counterparts in the rest of the world, with the opposite holding for Asia's emerging economies. During 1995-2008, Asian economies moved upstream relative to the rest of the world (Figure 4, left panel).

- Among individual countries, advanced Asian economies (Hong Kong SAR, Korea, Singapore) are generally located upstream in high-tech manufacturing, whereas emerging economies, such as China, India, and Vietnam, are generally located downstream (Figure 4, right panel).

- In low-tech manufacturing, both advanced and emerging Asian economies have moved slightly upward, but have remained downstream relative to the rest of the world. Unlike in high-tech manufacturing, there is no dichotomy in Asia between emerging and advanced economies in upstreamness and downstreamness in low-tech manufacturing.

Figure 4
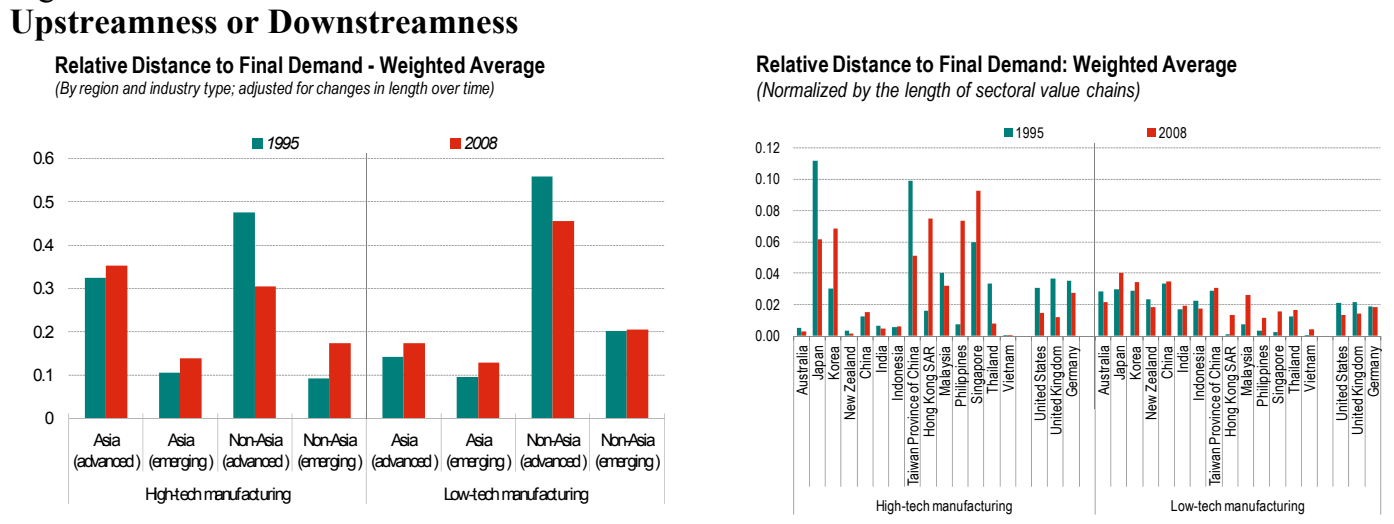

Sources: Organization for Economic Cooperation and Development and World Trade Organization, Trade in Value-Added database; and IMF staff estimates.

Note: Given that production processes have become more fragmented, the length-total number of production stages has increased. Therefore, the distance to final demand as shown in the chart in each year in each industry has been adjusted for changes in length. The underlying data for distance to final demand is based on Fally (2012).

\section{How CAN ECONOMIES InCREASE Their GVC PARTICIPATION?}

\section{A. Brief Overview of the Literature on Participation in Global Value Chains}

\section{GVC Participation: Benefits}

Countries benefit from integrating into GVCs through a number of channels. First, GVC participation increases comparative advantage in tasks owing to knowledge spillovers, technology transfers, and cost-savings among other factors, thus increasing the gains in productivity in tradable sectors. For instance, Baldwin and Yan (2014) examine whether the 
integration of Canadian manufacturing firms into a global value chain improves their productivity. By performing a micro-level panel data analysis, while controlling for the selfselection effect, ${ }^{1}$ they find that firms gained a 5 percent productivity advantage in the first year after entering into a GVC compared with non-GVC firms, with the productivity advantage accumulating to 9 percent four years after entering a GVC. On the other hand, firms that exited from a GVC suffered a productivity loss of 1 percent in the first year, and a cumulative productivity loss of 8 percent over a four-year horizon.

\section{GVC Participation: Drivers and Impediments}

As the WTO (2014) points out, country-specific determinants such as a favorable business climate and better fundamentals are conducive to GVC participation. They identify tariffs and other trade impediments as hindering GVC participation as well as the ability to capture a bigger share of value chains.

In the existing literature, tariffs are found to be particularly detrimental to GVC-related trade, because intermediate inputs may cross boarders multiple times. As Blanchard (2013) indicates, the fragmentation process in GVCs essentially increases the "effective rate of protection" even if tariffs and other trade costs remain unchanged.

In addition to tariffs, the joint WTO-OECD Global Review of Aid for Trade (2013) identifies three additional important barriers to participating in value chains: inadequate infrastructure, limited access to trade finance, and standards compliance. It also finds four supply-side constraints, namely the regulatory environment, business environment, transportation infrastructure, and labor skills. Likewise, Hummels et al. (2012) find that better transportation infrastructure and a conducive business climate have a positive impact on trade, while their empirical work also suggests that the most time-sensitive trade flows are those involving parts and components trade (i.e. intermediate goods).

\section{B. Empirical Analysis}

\section{Methodology}

We have two objective in this section : i) to assess the impact of tariffs on GVC participation both in terms of backward and forward linkages; ii) to identify drivers of participation in global value chains for high-tech and low-tech industries separately. Our empirical strategy relies on panel regressions with fixed effects to account for time-invariant country-pair idiosyncratic factors and global common shocks. Moreover, our GVC participation indices used in the regressions are measured in value-added trade terms at an annual frequency from 1995-2012, as opposed to the five periods that are readily available in the OECD TiVA database. In order to address further endogeneity concerns, we also use lagged explanatory variables.

As regards the first objective, we explore the effects of tariffs on total participation, as well as backward participation and forward participation separately for both high-tech and low-

\footnotetext{
1 "Self-selection effect" refers to the fact that more productive firms are more likely to self-select to join a GVC.
} 
tech manufacturing sectors. The estimation is based on the following specification, which includes country and time fixed effects:

$$
\left.\log (\text { GVC Participation })_{\mathrm{c}, \mathrm{t}}=\alpha_{\mathrm{t}}+\alpha_{\mathrm{c}}+\beta \log \text { (Tariff on Intermediate imports }\right)_{\mathrm{c}, \mathrm{t}-1}+\varepsilon_{\mathrm{c}, \mathrm{t}}
$$

Turning to the second objective, following the existing literature, we explore the determinants of participation, by regressing total GVC participation on level of development, infrastructure and human capital development, institutions and labor regulations, tariffs and other trade impediments. As before, these regressions are also run separately for high-tech manufacturing and low-tech manufacturing sectors using the below specification, which includes country and time fixed effects:

$\log (\text { GVC Participation })_{\mathrm{c}, \mathrm{t}}=\alpha_{\mathrm{t}}+\alpha_{\mathrm{c}}+\beta_{1} \log (\text { GDP per capita })_{\mathrm{c}, \mathrm{t}-1}+\beta_{2} \log (\text { Infrastructure \& Human Capital })_{\mathrm{c}, \mathrm{t}-1}+$ $\beta_{3} \log (\text { Institutions \& labor regulations) })_{\mathrm{c}, t-1}+\beta_{4} \log (\text { Tariffs \& Impediments })_{\mathrm{c}, \mathrm{t}-1}+\varepsilon_{\mathrm{c}, t} \cdot$

\section{Data}

Specifications above are estimated using annual data for 57 countries from 1995-2012.

\section{GVC Participation}

We obtain the GVC participation indices directly from the OECD-TiVA database for available years (i.e. 1995, 2000, 2005, 2008, 2009). We then construct the participation indices for the interim years and for outer years through 2012, following the procedure adopted in Duval and others (2014). Specifically, we obtain $D V A_{g v c}$ and $F V A_{x}$ from the above dataset, and define participation indices as:

$$
\begin{gathered}
\text { Forward Participation Index }=\left(\frac{D V A_{g v c}}{X}\right) * 100 \\
\text { Backward Participation Index }=\left(\frac{F V A_{x}}{X}\right) * 100 \\
\text { Total Participation Index }=\left(\left(\frac{D V A_{g v c}}{X}\right) * 100\right)+\left(\left(\frac{F V A_{x}}{X}\right) * 100\right)
\end{gathered}
$$

where $D V A_{g v c}$ is the domestic value added exported for partner country's re-exports, $F V A_{x}$ is the foreign value added embodied in exports, $\mathrm{X}$ is the gross exports, all measured in U.S. dollars.

\section{Tariffs}

We obtain tariff data from UNCTAD TRAINS database through WITS. Following BEC, SITC, and ISIC manuals, we extract intermediate goods tariffs separately for overall, hightech manufacturing, and low-tech manufacturing sectors.

As shown in Figure 5, historically, there is indeed a strong negative correlation between tariff rates on intermediate goods and GVC participation. Across Asia and elsewhere, economies facing higher tariffs on their intermediate goods imports are less likely to participate in GVCs. Notably, emerging Asian economies that participate less in GVCs impose higher effective tariff rates on intermediate imports. 
Figure 5

Tariffs and GVC Participation
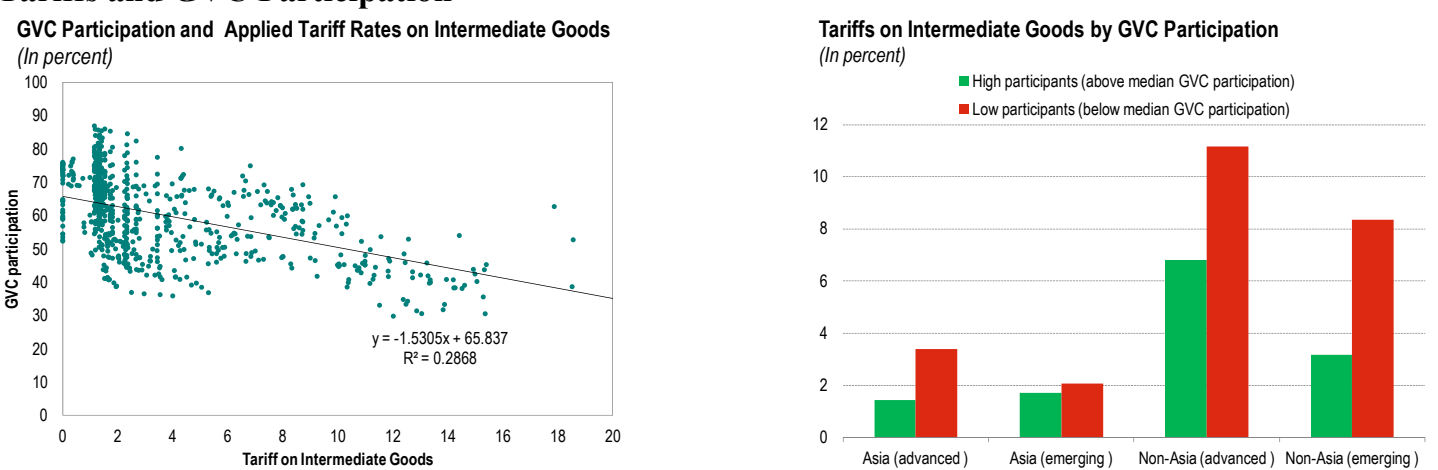

Sources: Organization for Economic Cooperation and Development and World Trade Organization, Trade in Value-Added database; UNCTAD TRAINS database; and IMF staff estimates.

\section{Level of Development}

We use real GDP per capita from the Penn Word table 8.0 to control for the level of economic development.

\section{Infrastructure}

Following Calderon and Serven (2004 and 2008), we construct a composite infrastructure measure to capture information in three key basic infrastructure sectors: communication, power, and road network. This infrastructure index is represented by the first principal component of five variables: communication (sum of total land-telephone lines, cell subscriptions, and internet users), electricity production per capita, road density, roads paved in percent of total roads, and electric power that is not lost in transmission and distribution:

$$
\text { Infrastructure index }=\alpha * \text { Communication }+\beta * \text { Electricity }+\gamma * \text { Road density }+\delta * \text { Paved roads }+\zeta * \text { Power }
$$
distribution

\section{Human Capital Development}

To capture human capital development, we use variables related to education and health. In order to differentiate between basic education and more skills-intensive education, we use two separate education variables: years of schooling, and quality of education system from the IMD Competitiveness Survey. Health expenditure in percent of GDP is used as a measure of health.

\section{Institutions and labor regulations}

We construct a composite governance indicator, using all six pillars of the World Bank Worldwide Governance Indicators database. The governance index is the first principle component of the following six variables: voice and accountability; political stability and absence of violence; government effectiveness; regulatory quality; rule of law; and control of corruption:

Governance index $=\alpha *$ voice and accountability $+\beta^{*}$ political stability $+\gamma^{*}$ government effectiveness $+\delta *$ regulatory quality $+\zeta^{*}$ rule of law $+\eta^{*}$ control of corruption

\section{Other Trade Impediments}

Apart from the tariffs explained at the beginning of this section, we use three other variables as trade impediments: the first impediment is distance (i.e. distance to all countries in the sample), weighted by the size of the economy. The other two indices capture the 
impediments to market openness: trade restrictiveness and investment restrictiveness. Both indices are from the World Freedom Index, and the inverse of the freedom indices are taken to capture the restrictiveness.

\section{Results: Impact of Tariffs on Intermediate Goods}

Table 1 presents the results of our model with tariff variables only. Tariffs on intermediate goods are associated with a significant negative effect on GVC participation, both backward and forward, in high-tech and low-tech manufacturing. Specifically, if a country moves from the 25 th to 75 th percentile of the cross-country distribution of tariffs (an increase in tariffs), GVC-linked trade participation is lowered by about $3 / 4$ of a percentage point of gross exports to $1 / 4$ percentage points, depending on the depth of backward and forward linkages. The estimated impact is

Table 1. Impact of Intermediate Goods Tariffs on Participation in Global Value-Chains

\begin{tabular}{|c|c|c|c|}
\hline & $(1)$ & $(2)$ & (3) \\
\hline & $\frac{\text { All sectors }}{\text { Coeff. }}$ & $\begin{array}{l}\text { Manufacturing in } \\
\text { high-tech sectors }\end{array}$ & $\begin{array}{c}\begin{array}{c}\text { Manufacturing } \\
\text { low-tech sectors }\end{array} \\
\text { Coeff. }\end{array}$ \\
\hline \multicolumn{4}{|c|}{ Panel A: Overall participation index (both forward and backward linkages combined) } \\
\hline $\log (\text { Tariffs })_{t-1}$ & $-0.118 * * *$ & $-0.153^{* * *}$ & $-0.076^{* * *}$ \\
\hline \multicolumn{4}{|c|}{ Panel B: Backward participation (Foreign value added component in exports) } \\
\hline $\log (\text { Tariffs })_{t-1}$ & $-0.221^{* * *}$ & $-0.173^{* * *}$ & $-0.188^{* * *}$ \\
\hline \multicolumn{4}{|c|}{ Panel C: Forward participation (Domestic value added component in supply-chain- } \\
\hline $\log (\text { Tariffs })_{t-1}$ & $-0.038^{* *}$ & $-0.105^{* * *}$ & $-0.053^{* *}$ \\
\hline No. of Obs. & 726 & 638 & 643 \\
\hline Robust S.E. & $\mathrm{Y}$ & $\mathrm{Y}$ & $\mathrm{Y}$ \\
\hline country \& time FE & $\mathrm{Y}$ & $\mathrm{Y}$ & $\mathrm{Y}$ \\
\hline
\end{tabular}
economically meaningful, particularly for low-tech manufacturing industries, given that the median backward and forward participation rates are typically around 3-6 percent (Figure 6, left panel).

Overall, the negative impact on backward participation - the import content in exports of the tariff-imposing country - is found to be larger than the negative impact on forward participation; that is, the extent to which domestic production of the tariff-imposing country is used as inputs by a third country. Thus, the distortionary effect on imports of the tariff imposer is higher than the carry-forward effect on the exports of the tariff imposer. Furthermore, the results are strongest in low-tech manufacturing.

Figure 6
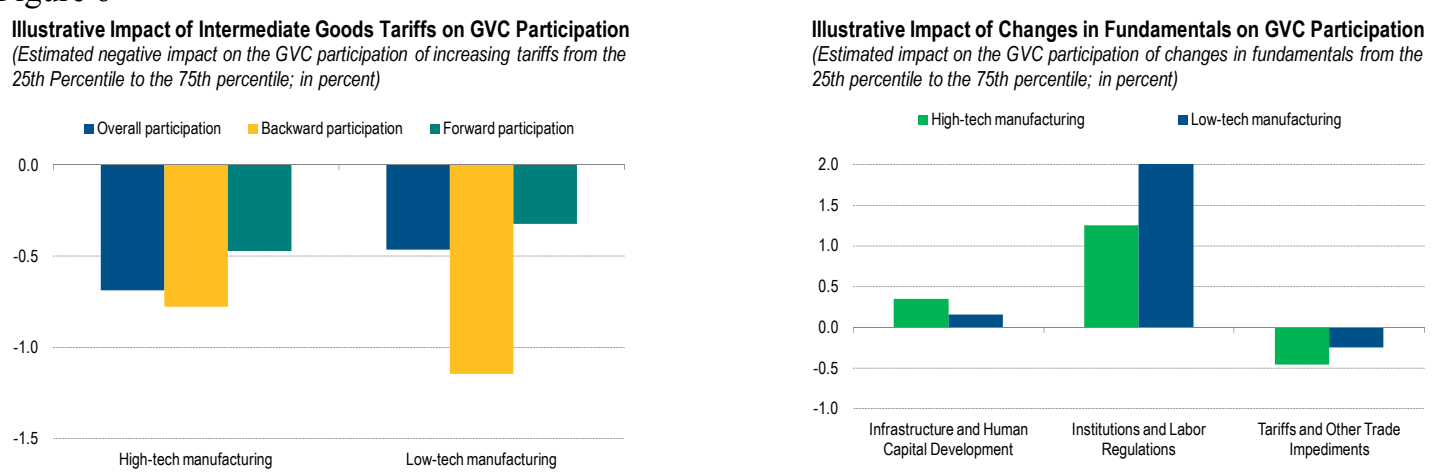

Source: IMF staff estimates.

Note: $\mathrm{GVC}=$ global value chain.

The illustrative impact of tariffs is not so small, as the GVC participation index subcategories are measured against (that is, the denominator) total exports in the economy; for instance, median backward and forward participation rates in the low-tech manufacturing sectors are typically around 3-6 percent. Underlying data on the effective tariff rates are measured using the weighted average across sectors. 


\section{Results: Impact of Fundamentals}

Table 2 presents the results of our specifications on drivers of participation in high-tech manufacturing and low-tech manufacturing, in addition to tariffs as a determinant. Column 1 shows the results for high-tech manufacturing sector, with those for low-tech manufacturing shown in column 2. ${ }^{2}$ Based on our estimates, and controlling for the level of income, we find that having better fundamentals such as a sound regulatory environment, human capital development, basic infrastructure, and lower tariffs and other trade barriers have benefited countries by raising their participation in GVCs.

While our results show that these drivers enhance GVC participation in general, industry-specific determinants of GVC participation also matter. As ADB (2013) notes, drivers across industries vary, specifically between low-tech and high-tech manufacturing. Indeed, our results illustrate that relevant variables vary between high-tech and low-tech manufacturing. For instance, while human capital may improve trade in GVCs, basic education is a significant driver of participation only for low-tech manufacturing. In high-tech manufacturing, what matters is the improvements to the quality of education, probably owing to the technology intensity of most of these industries. On the other hand, in low-tech manufacturing sectors, we find that less restrictive labor market regulations are associated with higher GVC participation (Figure 6, right panel).

Table 2. Drivers of Improving Participation in Global Value-Chains

\begin{tabular}{|c|c|c|}
\hline \multirow[t]{2}{*}{ Dependent Variable: $\log (\mathrm{PI})$} & $\begin{array}{l}\text { (1) } \\
\text { GVC Participation: High-tech } \\
\text { manufacturing }\end{array}$ & $\begin{array}{c}\text { (2) } \\
\text { GVC Participation: Low-tech } \\
\text { manufacturing } \\
\end{array}$ \\
\hline & Coeff. & Coeff. \\
\hline \multicolumn{3}{|c|}{ Level of Development } \\
\hline Real GDP per capita (lag 1) & $0.153 * * *$ & $-0.268 * * *$ \\
\hline \multicolumn{3}{|c|}{ Infrastructure and Human Capital Development } \\
\hline Infrastructure (lag 1) & $0.079 * * *$ & $0.128 * *$ \\
\hline Years of schooling (lag 1) & & $0.551 * *$ \\
\hline Quality of education system (lag 1) & $0.053 * *$ & \\
\hline Health expenditure (lag 1) & $0.079 * *$ & \\
\hline \multicolumn{3}{|c|}{ Institutions and Labor Regulations } \\
\hline Governance (lag 1) & $0.230 * * *$ & \\
\hline Lax labor regulations (lag 1) & & $0.264 * * *$ \\
\hline \multicolumn{3}{|c|}{ Tariffs and Other Trade Impediments } \\
\hline $\begin{array}{l}\text { Distance weighted by economic size } \\
\text { (lag 1) }\end{array}$ & & $-0.325 * * *$ \\
\hline Trade restrictiveness (lag 1) & $-0.115^{* *}$ & \\
\hline Investment restrictiveness (lag 1) & & $-0.364 * * *$ \\
\hline Tariff on intermediate goods (lag 1) & $-0.118 * * *$ & $-0.074 *$ \\
\hline No. of Obs. & 431 & 346 \\
\hline R-squared & 0.993 & 0.824 \\
\hline Robust S.E. & $\mathrm{Y}$ & $\mathrm{Y}$ \\
\hline Country \& time FE & $\mathrm{Y}$ & $\mathrm{Y}$ \\
\hline \multicolumn{3}{|l|}{$\begin{array}{l}\text { Source: IMF staff estimates. } \\
\text { Note: }{ }^{* * *} \mathrm{p}<0.01,{ }^{* *} \mathrm{p}<0.05,{ }^{*} \mathrm{p}<0.1\end{array}$} \\
\hline
\end{tabular}




\section{How Can an Economy Capture a Bigger Slice of the GVC Pie?}

The GVC pie is not sliced evenly, and capturing a bigger piece generally implies a higher level of GDP. In this section, we explore how a country's current positions in value chains affects its domestic value-added created in its production in a given industry.

\section{A. Empirical Analysis: Methodology}

A panel regression is used to assess which factors underlie an economy's ability to acquire a greater share of value added along the GVC. We differentiate high-tech from low-technology industries using the Eurostat definitions.

Estimation is based on the following with industry, country, and year fixed effects:

$$
\begin{gathered}
\log \left(D V A_{c, i, t}\right)=\alpha_{t}+\beta_{1} \log (G D P)_{c, i, t-1}+\beta_{2} \log (D F D)_{c, i, t-1}+\beta_{3} \log (E C I)_{c, i, t-1} \\
+\beta_{4} \log (\text { Tariff })_{c, i, t-1}+\varepsilon_{c, i, t}
\end{gathered}
$$

where $\log \left(D V A_{c, i, t}\right)$ is the logarithm of the share of domestic value added of country $c$ over the world in industry $i$ at time $t, \log (G D P)_{c, i, t-1}$ is the logarithm of the share of the Gross Domestic Product (GDP) of country $c$ over the world in industry $i$ at time $t-1$, $\log (D F D)_{c, i, t-1}$ is the logarithm of the distance of final demand (DFD) of country $c$ in industry $i$ at time $t-1$, and $\log (\text { Tariff })_{c, i, t-1}$ is the logarithm of the intermediate goods tariff country $c$ imposed on trade for industry $i$ at time $t-1$.

\section{Data}

We use country- and industry-level data for 57 countries for the following years: 1995, 2000, 2005, 2008, and 2009.

\section{Share of domestic value added}

We define our dependent variable as the logarithm of the share of domestic value added (DVA) of country $c$ over the world in industry $i$ at time $t$. The original DVA data comes from the 2013 release of the OECD-WTO TiVA database.

\section{GDP share}

Country $i$ 's share in global output is used as a control for relative economic size. We are controlling for the relative economic size because as an economy expands, its share of value added along a GVC should naturally rise and we are interested in the gain in share of value added along GVCs above and beyond the impact of economic size. GDP data are obtained from the IMF world Economic Outlook database.

\section{Distance to final demand (DFD)}

We obtain the DFD index at industry level, directly from the OECD-WTO TiVA database. The index measures the weighted average number of stages between an industry's production in a given country and its final demand, where the weight is the share of industry-wide output. Following Antràs et al. (2012) and Fally (2011), DFD is defined as:

$$
D_{i k}=u(I-G)^{-1}
$$


where $D_{i k}$ is the index for industry $\mathrm{k}$ in country $\mathrm{i}, \mathrm{u}$ is a unit vector, I is the identity matrix and $\mathrm{G}$ the Gosh inverse. The index is similar to the calculation of forward linkages in the context of an inter-country input output table.

\section{Economic complexity index (ECI)}

As explained in section IV above, we construct an ECI that reflects a given country's productive capabilities in each of its manufacturing industries. We use this measure as an explanatory variable in our cross-industry, cross-country regressions for domestic valueadded embodied in a given country's exports.

\section{Tariffs}

We include tariff in our model as an explanatory variable given that tariffs could lead to limited contributions from a country to a GVC. We obtain tariff data from UNCTAD TRAINS database through WITS. We extract tariffs at industry level for each manufacturing industry separately.

\section{B. Results: Capturing a Bigger Slice of the GVC Pie}

Key results, shown in Table 3, suggest that upstreamness and the ECI have increased the share of value added along a GVC captured by a country. On the contrary, in addition to hampering a country from participating in GVCs, a higher rate of tariffs on intermediate goods has led to a decreasing share of value added along a GVC captured by a country (Figure 7$)^{3}$. Specifically:

- Overall, economies in the upstream - measured by a longer distance to final demand - tend to capture a larger share of the value added generated in GVCs than more downstream economies. The impact of upstreamness on the ability to increase value added from GVCs is larger in high-tech manufacturing than in low-tech manufacturing. Intuitively, this may reflect the fact that upstreamness typically involves activities with higher value added such as R\&D (Figure 8), and R\&D plays a greater role in high-tech manufacturing (such as electronics). ${ }^{4}$

- $\quad$ Not surprisingly, countries with greater economic complexity have tended to capture a larger share of the value added from GVCs than those with lower economic complexity. The magnitude of the impact of economic complexity, however, is higher for low-tech manufacturing than for high-tech manufacturing.

- In addition to lower participation in GVCs, economies that impose higher tariff rates on intermediate goods are also less likely to increase their share of GVC value added conditional on their participation in these production networks. The negative impact is higher in high-tech manufacturing than in low-tech manufacturing.

\footnotetext{
${ }^{3}$ Specifically, in the absence of data at the product level, one cannot fully infer from the data the nature of the task-such as R\&D versus raw materials or assembling versus marketing - that each economy specializes in at each GVC position.

${ }^{4}$ These econometric results, which are based on industry-level data, need not be inconsistent with the "smiley- shape" hypothesis" discussed earlier, as which this applies at the individual product level.
} 
Table 3. Capturing a Bigger Slice in Global Value Chains

(1)

(2)

High-tech

Dependent Variable: $\log ($ DVA) manufacturing Low-tech manufacturing

\begin{tabular}{|c|c|c|c|c|}
\hline & & & \multirow{2}{*}{\multicolumn{2}{|c|}{$\begin{array}{ll}\text { Coeff. } & \text { S.E. }\end{array}$}} \\
\hline & Coeff. & S.E. & & \\
\hline $\log (\mathrm{GDP})$ & $0.874 * * *$ & $(0.12)$ & $0.678 * * *$ & $(0.10)$ \\
\hline $\log (\mathrm{DFD})$ & $1.065^{* *}$ & $(0.42)$ & $0.860 * *$ & $(0.43)$ \\
\hline $\log (\mathrm{ECI})$ & 0.531 & $(0.34)$ & $0.770 * * *$ & $(0.20)$ \\
\hline $\log$ (Tariff) & $-0.359 * * *$ & $(0.09)$ & $-0.211 * *$ & $(0.10)$ \\
\hline Observations & \multicolumn{2}{|c|}{723} & \multicolumn{2}{|c|}{939} \\
\hline R-squared & \multicolumn{2}{|c|}{0.882} & \multicolumn{2}{|c|}{0.77} \\
\hline Industry FE & \multicolumn{2}{|c|}{$\mathrm{Y}$} & \multicolumn{2}{|c|}{$\mathrm{Y}$} \\
\hline Country FE & \multicolumn{2}{|c|}{$\mathrm{Y}$} & \multicolumn{2}{|c|}{$\mathrm{Y}$} \\
\hline Year FE & \multicolumn{2}{|c|}{$\mathrm{Y}$} & \multicolumn{2}{|c|}{$\mathrm{Y}$} \\
\hline Cluster S.E. & \multicolumn{2}{|c|}{$\begin{array}{c}\text { Country and Industry } \\
\text { High-tech }\end{array}$} & \multicolumn{2}{|c|}{ Country and Industry } \\
\hline Classification & \multicolumn{2}{|c|}{ manufacturing } & \multicolumn{2}{|c|}{ Low-tech manufacturing } \\
\hline
\end{tabular}

Source: IMF staff estimates.

Note: $* * * \mathrm{p}<0.01,{ }^{* *} \mathrm{p}<0.05,{ }^{*} \mathrm{p}<0.1$

Figure 7

Assessing the link between Moving up GVCs, Upstreamness, Economic Complexity, and Tariffs

Estimated Coefficients for Distance to Final Demand, Economic Complexity, and Tariffs on Intermediate Goods

(In percent)

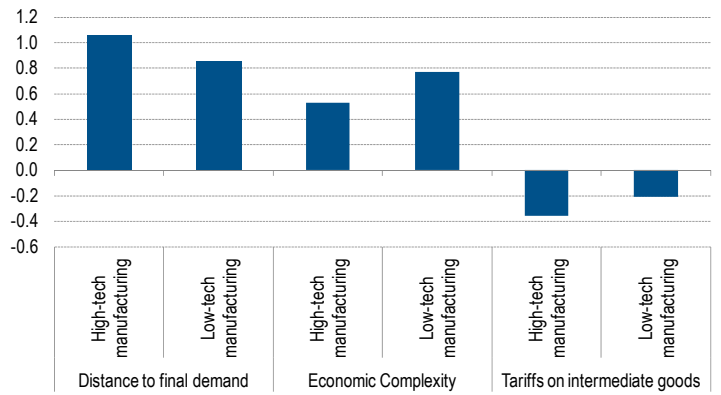

Source: IMF staff estimates.
Figure 8

Research and Development Expenditure and Upstreamness

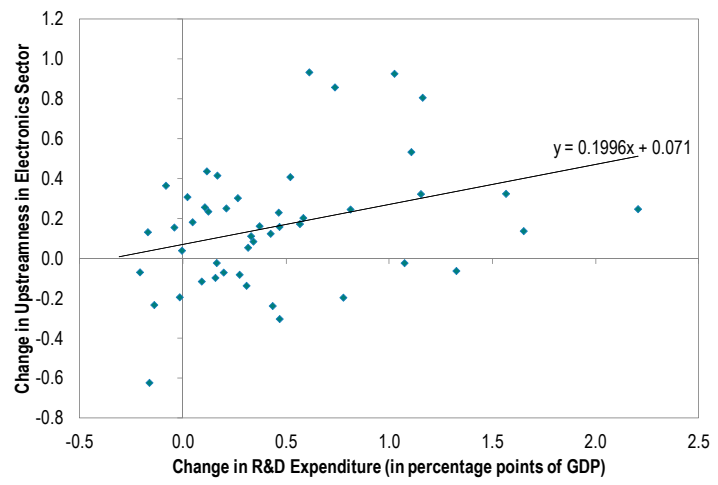

Sources: IMD World Competitiveness Database; Organization for Economic Cooperation and Development and World Trade Organization, Trade in Value-Added database; and IMF staff calculations. 


\section{CONCLUSIONS ANd Policy IMPlications}

- $\quad$ Asian economies have increased their participation in GVCs, captured an increasingly bigger slice of the GVC pie, and relocated toward upstream production. In addition, upstream production (particularly in high-tech manufacturing), a higher degree of economic complexity, and a lower level of tariffs on intermediate goods are associated with improved prospects for capturing a higher share of value added along a GVC.

- $\quad$ For Asia, integration into GVCs has provided an important path for transitioning from low to middle -income status and, in a few instances, for moving up to advanced country status. The main policy challenge is to secure these gains while exploring opportunities to capture an even larger slice of the GVC pie by repositioning toward higher value-added production. Against this background, key policy lessons include:

- Removing trade barriers - Our empirical analysis finds that tariffs on imports of intermediate goods reduce GVC participation, but also hamper the ability to capture a higher share of value added along a GVC once an economy is a member of a GVC. This is because when intermediate inputs cross borders multiple times it compounds the detrimental effect of a given trade barrier. In fact, within a GVC, imports are essentially inputs into exports, and thus any trade barrier imposed by an economy on its imports of intermediate goods is effectively a tax on that economy's own exports. Against this background, removing tariffs and other forms of trade barriers would benefit all GVC participants. More specifically, as indicated in IMF (2015), advanced economies should focus on opening services markets while emerging economies should move away from import-substitution policies and avoid protectionism in the form of nontariff barriers.

- Facilitating trade and regional cooperation-Apart from eliminating trade impediments, policymakers should go a step further to reduce costs of trade; for example by implementing trade-facilitating measures such as simplifying port and customs procedures. Regional trade agreements and cooperation will also help. In particular, given the high GVC participation of ASEAN economies, commitments for greater regional integration under the ASEAN Economic Community, beginning at the end of 2015, are welcome.

- Enhancing human capital formation and technology developmentUpstreamness is generally associated with capturing a higher share of value added along a GVC, particularly in high-tech manufacturing, likely reflecting the higher value added of R\&D and similar activities. Accordingly, shifting upstream requires a wide range of knowledge-and technology-enhancing measures. These include investing in human capital as well as measures to encourage innovation and R\&D. 
- Improving fundamentals - Enhanced participation in GVCs and economic sophistication also require a host of efficiency-enhancing structural reforms. These include better infrastructure, a more efficient regulatory framework, and stronger economic and legal institutions, as well as unwinding overly rigid labor market regulations.

- $\quad$ Mitigating GVC-related risks - In the presence of GVCs, a supply shock originating in one part of a GVC — such as the 2011 tsunami in Japan - may propagate to all downstream and upstream countries in the GVC unless there are built-in redundancies through duplication or sufficient inventories. Accordingly, participation in GVC networks may make countries more vulnerable to spillovers from external shocks, thus calling for more policy coordination across borders. Participants should strengthen their economies' resilience to macroeconomic shocks as well as ensuring adequate financial safety nets. 


\section{APPENDIX: ECONOMIC COMPLEXITY IN ASIA}

As shown in Section IV, economic complexity is an important factor determining if an economy can reap greater benefits from a GVC. Accordingly, this Appendix elaborates what economic complexity is and what factors underlie it.

\section{A. Key Facts}

Economic complexity is a concept developed by Hidalgo and Hausmann (2009) to capture the amount of productive knowledge and capabilities in an economy. Based on the idea that the output of an economy implicitly reveals the multiplicity of useful productive knowledge that is present within an economy, the economic complexity index (ECI) encompasses two aspects: diversity, pertaining to the number of distinct products that a country makes; and ubiquity, the number of countries that also make the same product. An economy that is able to produce and export a wide variety of products (high diversity) and those that are more rare (less ubiquitous among other countries) are ranked high on ECI. Accordingly, a higher ECI suggests that a country is capable of producing a diverse range of products which are less commonly produced by other countries. Furthermore, Hidalgo and Hausmann (2009) find that a high ECI leads to faster growth in per capita income over time (Figure A1). Specifically, a one standard deviation increase in complexity is associated with a subsequent growth acceleration of 1.6 percent per year.

Figure A1

\section{Economic Complexity}

Economic Complexity and GDP per capita: 2008

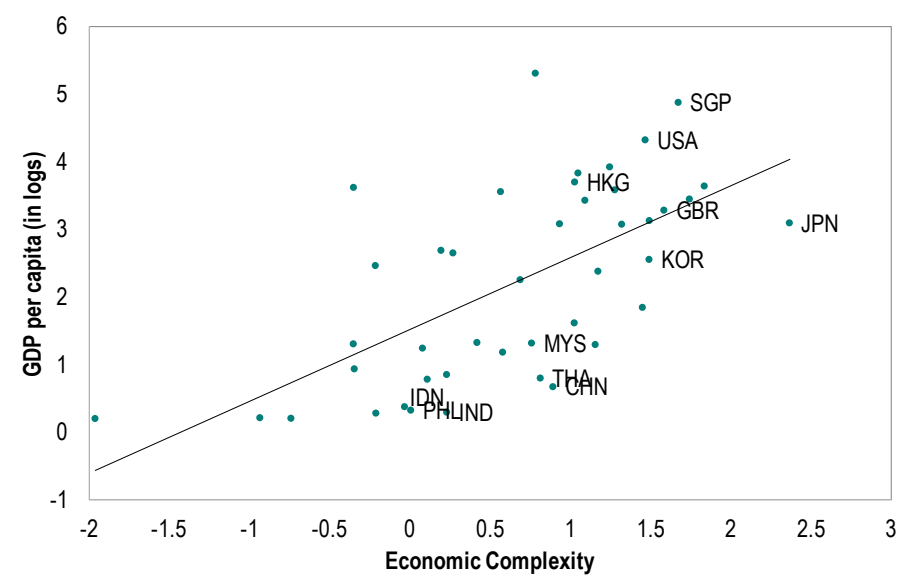

Sources: The ECI is from the Atlas of Economic Complexity; Penn World Table 8.0; United Nations, COMTRADE database; and IMF staff estimates.

Notes: The ECI is calculated using an iterative method, where the average value of the measure is calculated with the initial values being a country's diversification and a product's ubiquity; measured as a z-score. Country abbreviations in panel 1 use the threeletter International Organization for Standardization codes. Non-Asia (advanced) = Austria, Canada, Denmark, France, Finland, Greece, Ireland, Italy, Netherlands, Norway, Portugal, Spain, United States, and United Kingdom. Non-Asia (emerging) = Argentina, Bulgaria, Brazil, Chile, Hungary, Mexico, Poland, Saudi Arabia, Turkey, and South Africa. 
As shown in Figure A2, while the ECI has generally increased across the globe, compared with economies at similar income levels outside Asia, the ECI for Asia is lower. Indeed, key emerging economies in Asia, including China, India, and Indonesia, have a relatively low ECI. Likewise, advanced economies in Asia, such as Japan and Korea, have lower ECIs than Germany, the United Kingdom, and the United States (Figure A3). Relative to the rest of the world, the ECI - which captures productive knowledge and capabilities and has been shown to be positively correlated with faster income growth-has also risen in Asia. The ECI is found to be driven by better institutional quality, enhanced macroeconomic stability, and greater trade openness. However, ECIs for Asia, including China and India, remain low.

Figure A2

ECl by Region (Weighted by PPP GDP Share)

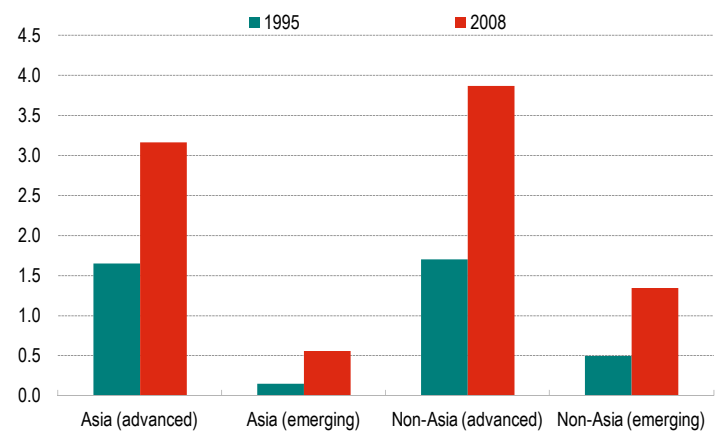

Figure A3

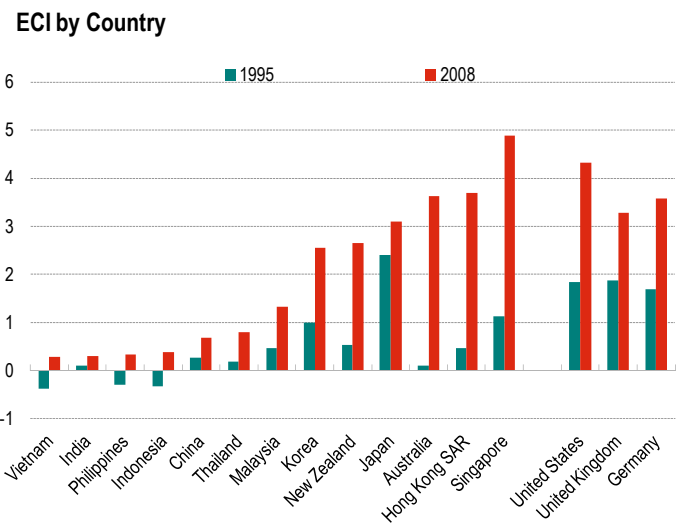

Sources: The ECI is from the Atlas of Economic Complexity; Penn World Table 8.0; United Nations, COMTRADE database; and IMF staff estimates.

Notes: The ECI is calculated using an iterative method, where the average value of the measure is calculated with the initial values being a country's diversification and a product's ubiquity; measured as a z-score. Country abbreviations in panel 1 use the three-letter International Organization for Standardization codes. Non-Asia (advanced) = Austria, Canada, Denmark, France, Finland, Greece, Ireland, Italy, Netherlands, Norway, Portugal, Spain, United States, and United Kingdom. Non-Asia (emerging) = Argentina, Bulgaria, Brazil, Chile, Hungary, Mexico, Poland, Saudi Arabia, Turkey, and South Africa.

\section{B. What Underlies Economic Complexity?}

Despite its importance, there has been little research on what drives the ECI. Against this background, we assess the key drivers of the ECI. In the absence of a theoretical model for the drivers of the ECI, the Bayesian Model Averaging (BMA) approach is used to select from a wide range of factors that may explain the ECI. Specifically, we start with a large range of plausible socioeconomic variables that might affect the ECI and use the BMA to narrow down the list of variables, with the variables with a probability of inclusion below 0.5 eliminated from the selection. Based on Bayesian Model Averaging, five variables are selected, including geographical distance from the rest of the world, size of government, trade openness, and composite institutional quality. 


\section{Econometric estimation and results}

Based on the BMA, the ECI is then regressed on these five variables using the following panel equation, with country fixed effects for 93 countries during 1980-20105:

$$
\begin{aligned}
\mathrm{ECI}_{\mathrm{c}, \mathrm{t}}= & \alpha_{\mathrm{c}, \mathrm{t}}+\beta_{1}(\mathrm{GDP} \text { per capita })_{\mathrm{c}, \mathrm{t}-1}+\beta_{2}(\text { Trade Openness })_{\mathrm{c}, \mathrm{t}-1}+\mathrm{B} 3(\text { Distance })_{\mathrm{c}, \mathrm{t}-1}+\beta_{4}(\text { Size of } \\
& \text { Government/GDP })_{\mathrm{c}, \mathrm{t}-1}+\mathrm{B} 5(\text { Composite Institutional Quality })_{\mathrm{c}, \mathrm{t}-1}+\alpha_{\mathrm{c}}+\varepsilon_{\mathrm{c}, \mathrm{t} .}
\end{aligned}
$$

The main results, shown in Table A1, suggest that the ECI is positively correlated with greater trade openness and a higher institutional quality, but negatively correlated with the geographic distance from the rest of the world and the size of government.

Table A1. Drivers of Economic Complexity (Panel BMA Best Specification)

\begin{tabular}{lcc}
\hline \multirow{2}{*}{ Dependent Variable: ECI } & \multicolumn{2}{c}{$(1)$} \\
\cline { 2 - 3 } & \multicolumn{2}{c}{ Coeff. } \\
GDP per capita (lag 1) & -0.027 & $(0.026)$ \\
Trade openness (lag 1) & $0.341^{* * *}$ & $(0.078)$ \\
Distance weighted by GDP (lag 1) & $-0.901^{* * *}$ & $(0.118)$ \\
Size of government (lag 1) & $-0.095^{* * *}$ & $(0.026)$ \\
Composite institutional quality (lag 1) & $0.170^{* * *}$ & $(0.025)$ \\
\hline Observations & \multicolumn{2}{c}{136} \\
R-squared & \multicolumn{2}{c}{0.773} \\
Robust SE & \multicolumn{2}{c}{$\mathrm{Y}$} \\
Time dummy & \multicolumn{2}{c}{$\mathrm{Y}$} \\
\hline
\end{tabular}

Source: IMF staff estimates.

Note: Economic Complexity Index; BMA = Bayesian Model Averaging.

$* * * \mathrm{p}<0.01, * * \mathrm{p}<0.05, * \mathrm{p}<0.1$

${ }^{5}$ To address the endogeneity issue, a two-step, least-square approach is estimated where the GDP-per-capita variable is estimated in the first step and the corresponding predicted values are used for the ECI regression. 


\section{REFERENCES}

Asian Development Bank, 2013, Key Indicators for Asia and the Pacific, 2013; "Asia's Economic Transformation: Where to, How, and How Fast?" $44^{\text {th }}$ edition, (Manila)

Baldwin, J., and B. Yan, 2014, "Global Value Chains and the Productivity of Canadian Manufacturing Firms," Economic Analysis Research Paper Series (Ottawa, Statistics Canada).

Blanchard, E., 2013, "What Global Fragmentation Means for the WTO: Article XXIV, Begind-the-Border Concessions, and A New Case for WTO Limits on Investment Incentives," WTO Working Paper ERSD-2013-03 (Geneva: World Trade Organization).

Dedrick, Jason, Kenneth L. Kraemer, and Greg Linden, 2010, "Who Profits from Innovation in Global Value Chains?: A Study of the iPod and Notebook PCs," Industrial and Corporate Change, Vol. 19, No. 1, pp. 81-116.

Fally, T., 2012, "Production Staging: Measurement and Facts," unpublished, University of Colorado-Boulder.

Garcia-Herrero, A., and T. Koivu, 2009, "China's Exchange Rate Policy and Asian Trade," BIS Working Papers No. 282 (Switzerland: Bank for International Settlements).

Hidalgo, C., and R. Hausmann, 2009, "The Building Blocks of Economic Complexity", $P N A S$, Vol. 106, No. 26, pp. 10570-10575.

Hausmann, R., C.A. Hidalgo, S. Bustos, M. Coscia, S. Chung, J. Jimenez, A. Simoes, and M.A. Y1ldirım, 2011, The Atlas of Economic Complexity, New Hamphire: Puritan Press

Hummels, D., and Schaur, G., 2012, “Time as a Trade Barrier”, NBER Working Paper No. 17758 (Cambridge, Massachusetts: National Bureau for Economic Research).

International Monetary Fund, 2013, Trade Interconnectedness: The World with Global Value Chains (Washington).

International Monetary Fund, 2015, Chapter 3, Asia Pacific Regional Economic Outlook. "Reaping the Benefits from the Global Value Chains" (Washington).

International Monetary Fund, 2015, Review of the Role of Trade in the Work of the Fund, (Washington).

Koopman, Robert, William Powers, Zhi Wang and Shang-Jin Wei, 2010, "Give Credit Where Credit Is Due: Tracing Value Added in Global Production Chains," NBER Working Paper 16426 (Cambridge, MA: National Bureau of Economic Research). 
Organization for Economic Cooperation and Development, 2013, Interconnected Economies: Benefiting from Global Value Chains, (Paris). http://dx.doi.org/10.1787/9789264189560-en.

OECD, UNCTAD, and WTO, 2013, "Implications of Global Value Chains for Trade, Investment, Development and Jobs ” prepared for the G-20 Leaders Summit Saint Petersburg (Russian Federation), http://www.oecd.org/sti/ind/G20-Global-ValueChains-2013.pdf.

Oikawa, H., 2008, "Empirical Global Value Chian Analysis in Electronics and Automobile Industries: An application of Asian International-Input-Output Tables" (Tokyo: Institute of Developing Economies).

Riad, Nagwa, Luca Errico, Christian Henn, Christian Saborowski, Mika Saito, and Jarkko Turunen, 2012, Changing Patterns of Global Trade, (Washington: International Monetary Fund).

Shin, N., Kenneth L. Kraemer, and Jason Dedrick, 2012, "Value Capture in the Global Electronics Industry: Empirical Evidence for the "Smiling Curve" Concept", Journal of Industry and Innovation, Vol. 19, No. 2, pp. 89-107.

World Trade Organization, 2014, World Trade Report, "The Rise of Global Value Chains", (Geneva). 